\title{
Low-Grade Osteosarcoma, Review of 15 Cases in a Series of 156 Osteosarcoma Cases
}

\section{Düşük Dereceli Osteosarkom, 156 Osteosarkom Olgusu Arasında 15 Olguluk Seriye Bakış}

\author{
Hilal Serap ARSLAN', Övgü AYDIN', Sergülen DERVişOĞLU', Didem ÇOLPAN ÖKSÜZ², Fatih KANTARCI', \\ Murat $\mathrm{HIZ}^{4}$, Fazilet ÖNER DINÇBAŞ ${ }^{2}$, Nil MOLINAS MANDEL ${ }^{5}$ \\ Departments of ${ }^{1}$ Pathology, ${ }^{2}$ Radiation Oncology, ${ }^{3}$ Radiology, ${ }^{4}$ Orthopedics and Traumatology and ${ }^{5}$ Internal Medicine, Medical Oncology, Istanbul University, \\ Cerrahpaşa Faculty of Medicine, ISTANBUL, TURKEY
}

\section{ABSTRACT}

Objective: Osteosarcoma of the bone accounts for approximately $20 \%$ of all primary malignant bone tumors. Most cases $(75-85 \%)$ are high-grade osteosarcomas. We aimed to introduce low-grade osteosarcomas that we found by retrospectively scanning our archives because of the diagnostic difficulties, rarity and different therapeutic approach required.

Material and Method: We found 156 osteosarcoma cases in the archives of the Department of Pathology of Istanbul University, Cerrahpaşa Faculty of Medicine covering the period 2000 to 2010. These cases included 141 high-grade and 15 low-grade osteosarcomas.

Results: Low-grade osteosarcomas made up $10.4 \%$ of all osteosarcomas. Age and sex distribution were 19 to 54 (median 33.6) with 9 females and 6 males. Most cases were located in the distal femur while others were in the proximal tibia, the left wrist, the distal tibia and the right knee. The tumors were generally made up of relatively well-formed trabeculae of woven bone surrounded by a moderately cellular spindle cell proliferation entangled in collagen fibers. Thirteen cases were reported as parosteal osteosarcoma, one as intramedullary well-differentiated osteosarcoma, and one as low-grade osteosarcoma metastasis in the lung.

Conclusion: Low-grade osteosarcomas account for approximately $3-5 \%$ of all osteosarcomas. They are more commonly seen in women and 9 cases out of 6 were female in our series. The average age was 33.6 (19-54). The distal femur was the most common localization as is typical in osteosarcomas. In contrast to high-grade lesions, surgery will be sufficient in low-grade osteosarcomas. The survival rate ranges from $90 \%$ to $100 \%$. Differentiating low-grade osteosarcomas from high-grade osteosarcomas and benign lesions and using a multidisiplinary approach for the diagnosis, treatment and follow-up periods are of vital importance.

Key Words: Osteosarcoma, Juxtacortical, Prognosis

\section{Öz}

Amaç: Osteosarkomlar primer malign kemik tümörlerinin \%20’sini oluşturmaktadır. Olguların çoğu ( \%75-85) yüksek dereceli osteosarkomlardır. Nadir rastlanması, tanı güçlügü ve farklı tedavi yaklaşımı nedeniyle retrospektif arşiv taramasıyla saptanan düşük dereceli osteosarkom olgularını sunmayı amaçladık.

Gereç ve Yöntem: İ.Ü. Cerrahpaşa Tip Fakültesi Patoloji Anabilim Dalı'nda 2000-2010 yılları arası arşivinde 156 osteosarkom olgusu bulunmuştur. Bu olguların 141'i yüksek dereceli, 15'i ise düşük dereceli osteosarkom tanısı almıştır.

Bulgular: Düşük dereceli osteosarkomlar, osteosarkomlar içinde \%10,4'lük bir orandadır. Olguların 9'u kadın, 6'sı erkektir. Yaş dağılımı 19 ile 54 arasındadır (ortalama 33,6). Yedisi femur distali, biri tibia proksimali, biri sol el bileği, biri tibia distali, biri sağ diz yerleşimli olup 3 olgunun yerleşim yerleri bilinmemektedir. Bir olgu akciğer metastazı kayıtlıdır. Tümörler genelde orta-belirgin iğsi hücre proliferasyonu ve kollagen liflerle çevrili iyi şekillenmiş ağsı kemik trabeküllerinden yapılıdır. On üç olgu parosteal osteosarkom, bir olgu intramedüller düşük dereceli osteosarkom/fibroblastik, bir olgu ise akciğerde düşük dereceli osteosarkom metastazı tanısı almıştır.

Sonuç: Düşük dereceli osteosarkomlar, tüm osteosarkomların yaklaşık \%3-5’ini oluşturmaktadır. Düşük dereceli osteosarkomlar kadınlarda daha sık görülür. Olgularımızda da 9:6 oranında kadın üstünlüğü görülmüştür. Ortalama görülme yaşı 33,6 (19-54) olarak izlenmiştir. En sık yerleşim yeri olan femur distal uç olup olgularımızda da benzer özellik göstermektedir. Yüksek dereceli osteosarkomlardan farklı olarak düşük dereceli osteosarkomlarda cerrahi tedavi tek başına yeterlidir. Beklenen yaşam süresi \%90-100 arasında değişmektedir. Oldukça iyi prognoza sahip bu tipin yüksek dereceli tipten ayrılması, ayırıcı tanı güçlüğü oluşturan selim lezyonlardaki örtüşmenin iyi değerlendirilmesi ve multidisipliner yaklaşımlarla hasta tanı, tedavi ve izlem planının sürdürülmesi yaşamsal önem taşımaktadır.

Anahtar Sözcükler: Osteosarkom, Jukstakortikal, Prognoz 


\section{INTRODUCTION}

Osteosarcomas make up $20 \%$ of primary malignant bone tumors (1). Most cases (75-85\%) are high-grade osteosarcomas (conventional and histological subtypes: Osteoblastic, Telangiectatic, Fibroblastic, Chondroblastic Small cell, etc.). Others are high-grade secondary osteosarcomas (10\%), intramedullary well-differentiated osteosarcomas (1\%), surface osteosarcomas (juxtacortical osteosarcoma, parosteal osteosarcoma) (3-5\%), and juxtacortical intermediate-grade chondroblastic osteosarcomas and periosteal osteosarcomas (2-4\%) (2). Cases are older than 25 years in $60 \%$ and older than 40 years in $13-30 \%$ with slight male predominance (3). The location is usually the metaphysis of long bones and especially the distal femur, tibia upper end and humerus upper end (4). The diaphysis and epiphysis are involved rarely and the flat bones (skull and facial bones, pelvis, scapula) (5), the vertebrae (6) and short bones can be affected less frequently (7). Radiological investigation reveals a large mass with irregular borders and a destructive, mixed, lytic and blastic character and frequent soft tissue invasion in high-grade osteosarcoma cases whereas low-grade cases are sclerotic and generally arise from the cortical aspect.

Low-grade osteosarcomas consist of parosteal osteosarcomas with a rate of $3-5 \%$ and intramedullary low-grade osteosarcomas with a rate of 1\% (1). Parosteal osteosarcomas are seen at a slightly later age than conventional type and are frequently seen in the 3rd to 4 th decade. They are more frequent in females in contrast to high-grade osteosarcomas. The typical location is the distal femur body, posterior aspect of metaphysis (1). Intramedullary low-grade osteosarcomas are seen in the 3rd decade with equal sex distribution and are usually located in the femur or tibia $(8,9)$. We aimed to present the low-grade osteosarcoma cases we found on a retrospective archive screening as they are rare, the diagnosis is difficult and a different treatment approach is needed.

\section{MATERIAL and METHOD}

We found a total of 156 osteosarcoma cases between 2000 and 2010 in the archives of Istanbul University, Cerrahpaşa Faculty of Medicine, Department of Pathology. 141 of these were high-grade and 15 were low-grade osteosarcomas. The cases were re-evaluated after grouping according to age, gender, location and microscopical features.

\section{RESULTS}

Low-grade osteosarcomas made up 10.4\% (15/156) of all osteosarcomas (Figure 1). There were 9 females and 6 males
(Figure 2). The age distribution was 19 to 54 (mean 33.6 years). The most frequent location was the distal femur ( 7 cases) followed by the proximal tibia ( 1 case), left wrist ( 1 case), distal tibia ( 1 case) and right knee (1 case). The location was unknown in 3 cases. One case had a record of lung metastases (Figure 3).

Radiological investigation showed an expansive, sclerotic lesion extending to the surrounding soft tissue in most cases (Figure 4). One case had a destructive mass lesion that extended to the surrounding soft tissue and the PET CT showed an appearance consistent with metastasis in the iliac lymph nodes (Figure 5).

Microscopic examination showed that the tumors consisted of moderate to marked spindle cell proliferation and wellformed woven bone trabeculae surrounded by collagen fibers (Figure 6A, B). Mitosis was very rare and the cells did not show marked cytological atypical features. The tumor contained irregular woven bone in some areas and resembled fibrous dysplasia. These tumors can be differentiated from fibrous dysplasia with their permeative pattern (10-12). There were also parosteal osteosarcoma cases with osteochondromatous areas among our cases. However, the chondrocyte arrangement in our parosteal osteosarcoma cases was irregular in contrast to the columnar arrangement in the cap of the osteochondroma. It is also possible to see fatty or hematopoietic bone marrow tissue between the bone trabeculae in osteochondroma while our parosteal osteosarcoma cases had spindle cell proliferation (13). We also observed myofibroblastic spindle cell proliferation similar to myositis ossificans but the differential diagnosis was facilitated by the lack of a peripheral area showing maturation towards bone and the radiological features (14). One tumor had occasional areas similar to a giant cell tumor. We first received a trucut biopsy material that contained giant cell areas of this tumor and the diagnosis was giant cell lesion in soft tissue. However, the curettage material showed areas resembling a giant cell tumor and a component of seconary aneurysmal bone cyst. The resection material then revealed that the main tumor consisted of anastomosing bone trabeculae separated by fibrous tissue that made up of fibroosseous tumor, accompanied by giant cells. There was moderate nuclear pleomorphism in the spindle cells of the tumor (Figure 7A-C). This case was diagnosed as low-grade fibroblastic type intramedullary osteosarcoma containing areas resembling fibrous dysplasia. Thirteen cases received a diagnosis of parosteal osteosarcoma while one case was diagnosed as pulmonary low-grade osteosarcoma metastasis. 


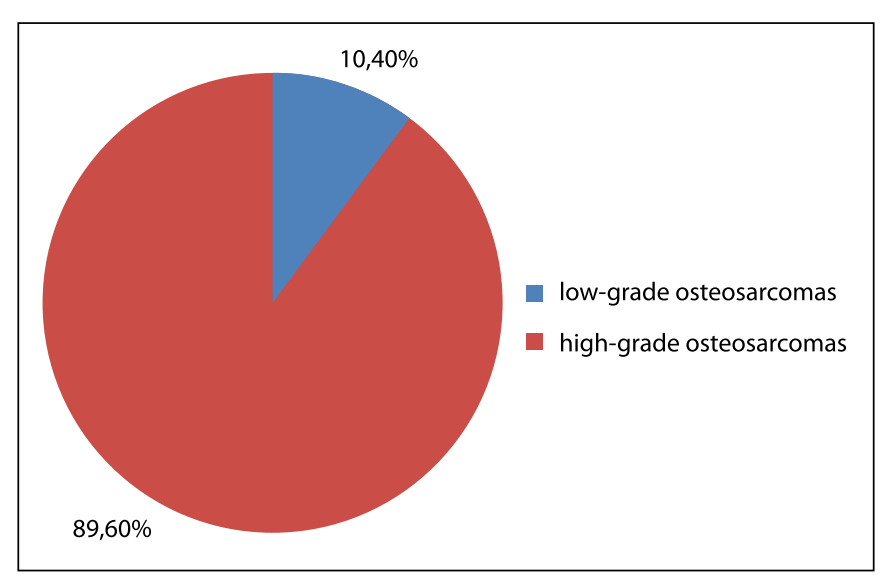

Figure 1: The 156 osteosarcoma cases were divided into 141 with high-grade osteosarcoma (89.6\%) and 15 with low-grade osteosarcoma (10.4\%).

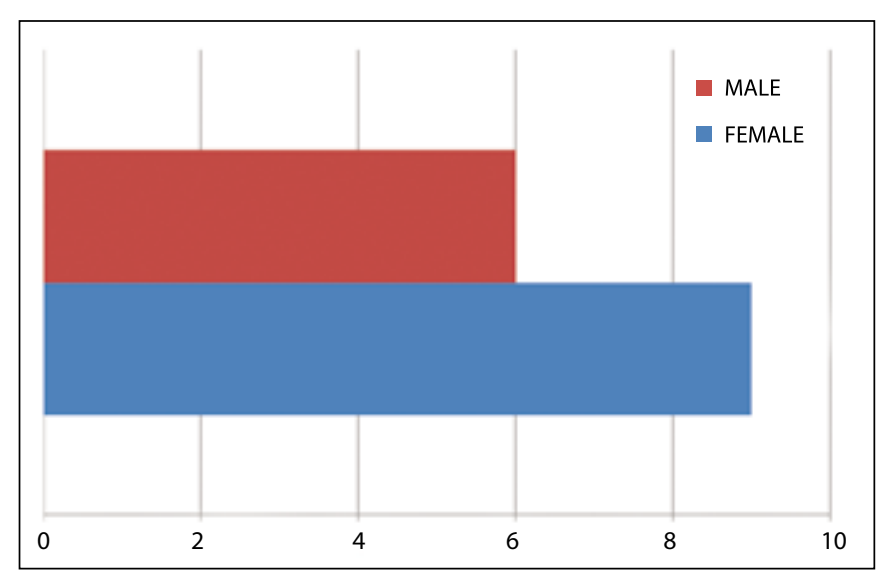

Figure 2: Gender distribution of low-grade osteosarcoma cases: 9 females, 6 males.

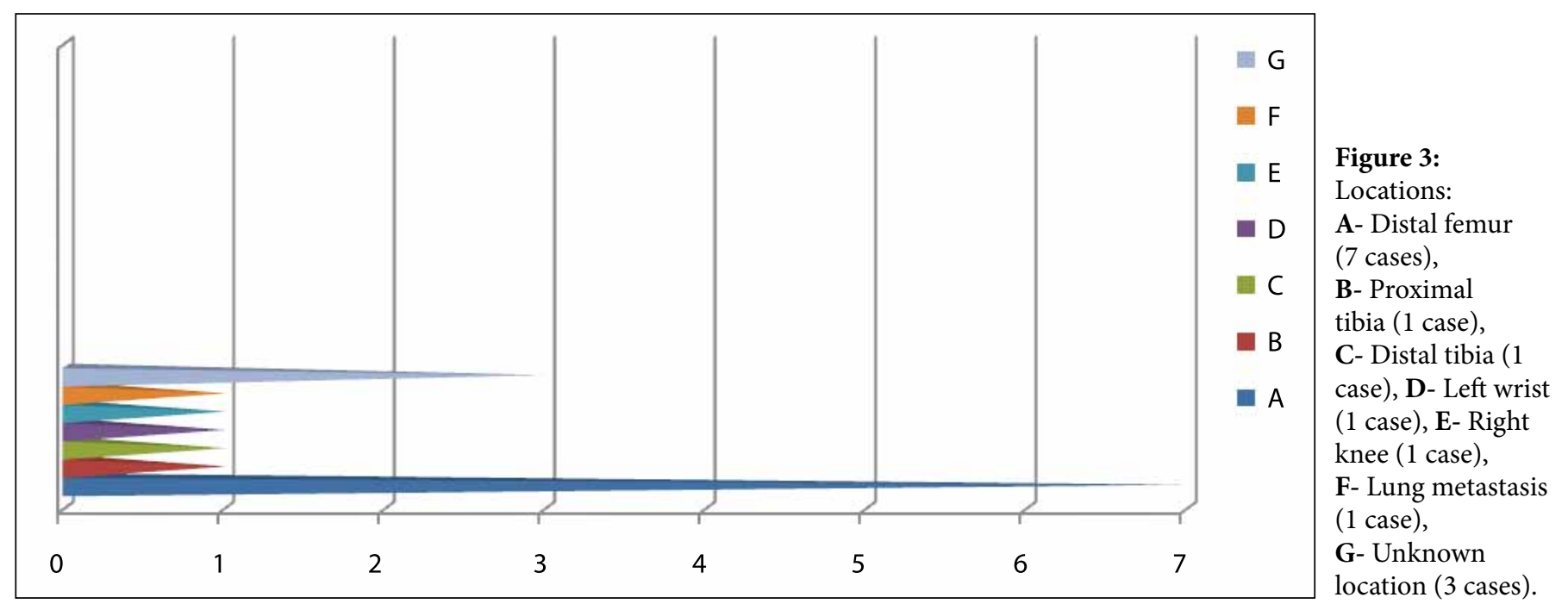

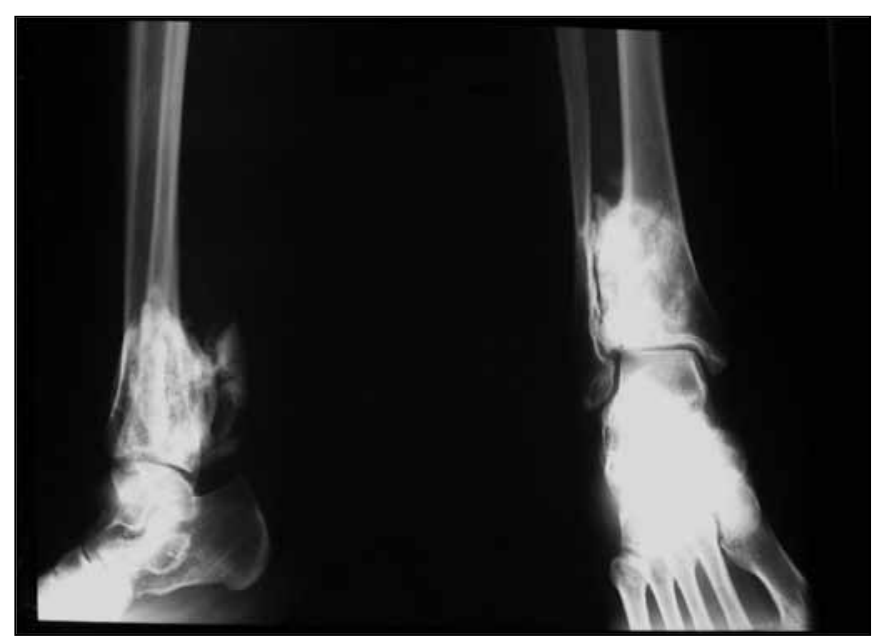

Figure 4: Direct x-ray - Right tibia distal posterolateral side has an expansive, sclerotic lesion that extends to the surrounding soft tissue, which shows increased opacity consistent with osteoblastic activity increase.

\section{DISCUSSION}

Osteosarcomas make up 20\% of primary malignant bone tumors (1). Most (75-85\%) are high-grade osteosarcomas. Low-grade osteosarcomas make up approximately 3-5\% of all osteosarcomas (2). In our series, rate for low-grade osteosarcomas was $10.4 \%$ among all osteosarcomas (15/156).

High-grade osteosarcomas are seen more commonly in males (3) while low-grade osteosarcomas (and especially parosteal osteosarcoma) are more frequent in females (1). We had a female predominance at a rate of 9:6. The mean age for low-grade osteosarcomas is the 3 rd to 4 th decades (3) and was similarly 33.6 (19-54) in our cases. The most common locations for low-grade osteosarcomas are reported as the distal femur, proximal tibia and humerus 


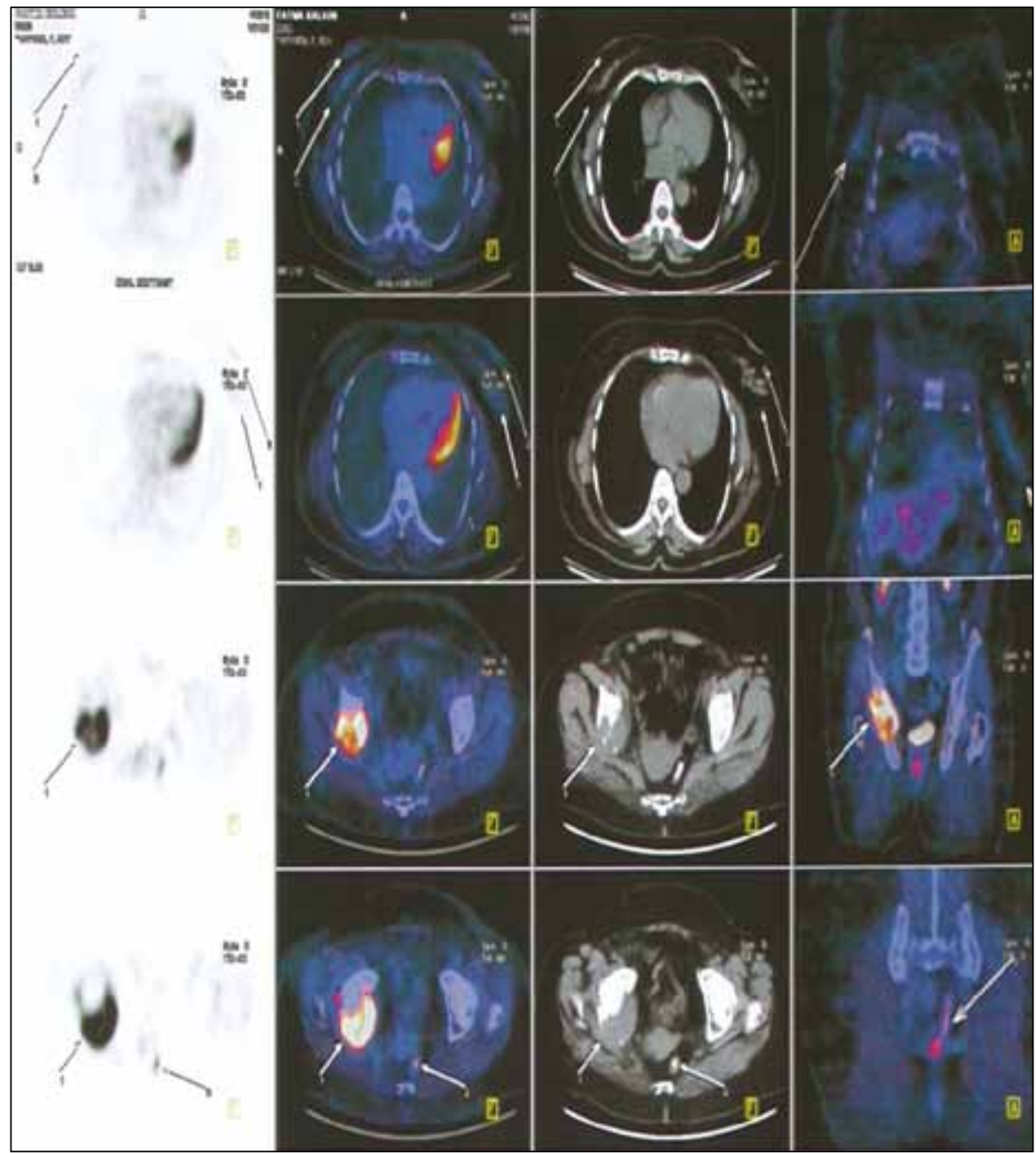

Figure 5: PET-BT- Increased fluorodeoxy glucose (FDG) enhancement in the right acetabular area, appearance consistent with metastasis in the precoccygeal space and left internal iliac chain.
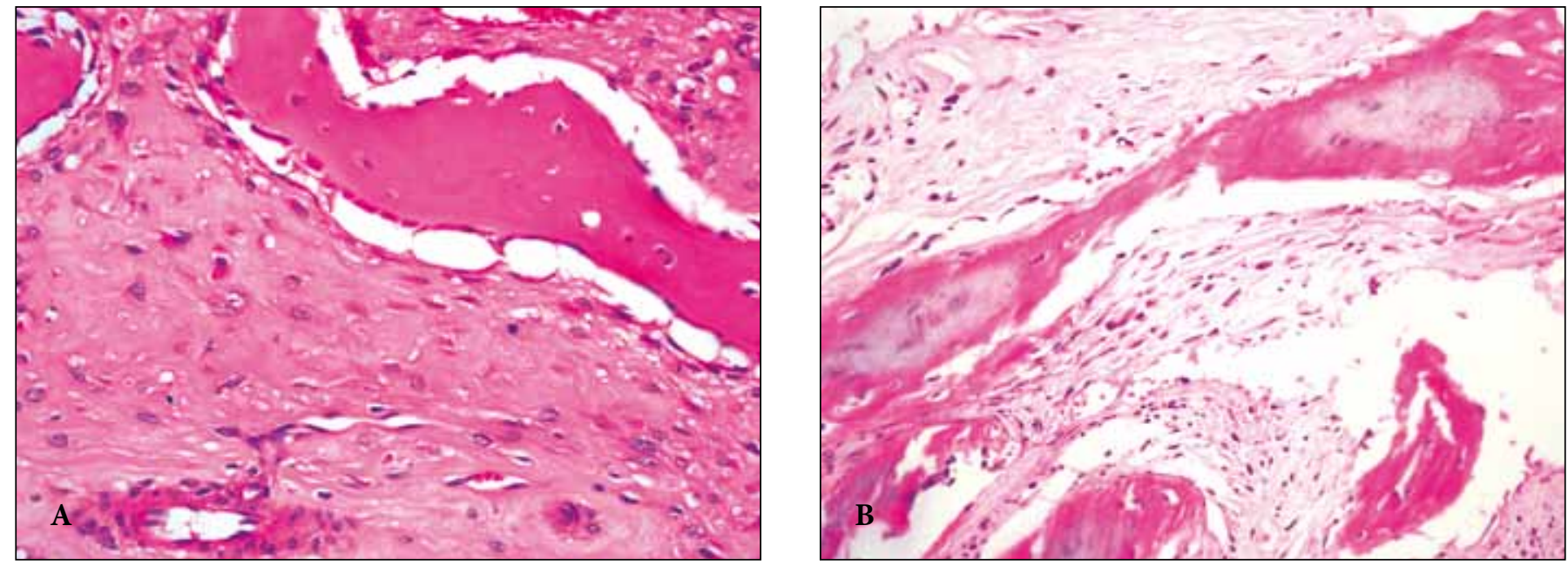

Figure 6: A) Parosteal osteosarcoma showing well-formed bone trabeculae inside collagenized tissue and moderate to marked spindle cell proliferation $(\mathrm{H} \& \mathrm{E}, \mathrm{x} 400) \mathrm{B})$ A hypocellular spindle-like stroma separates the bone trabeculae $(\mathrm{H} \& \mathrm{E}, \mathrm{x} 400)$. 

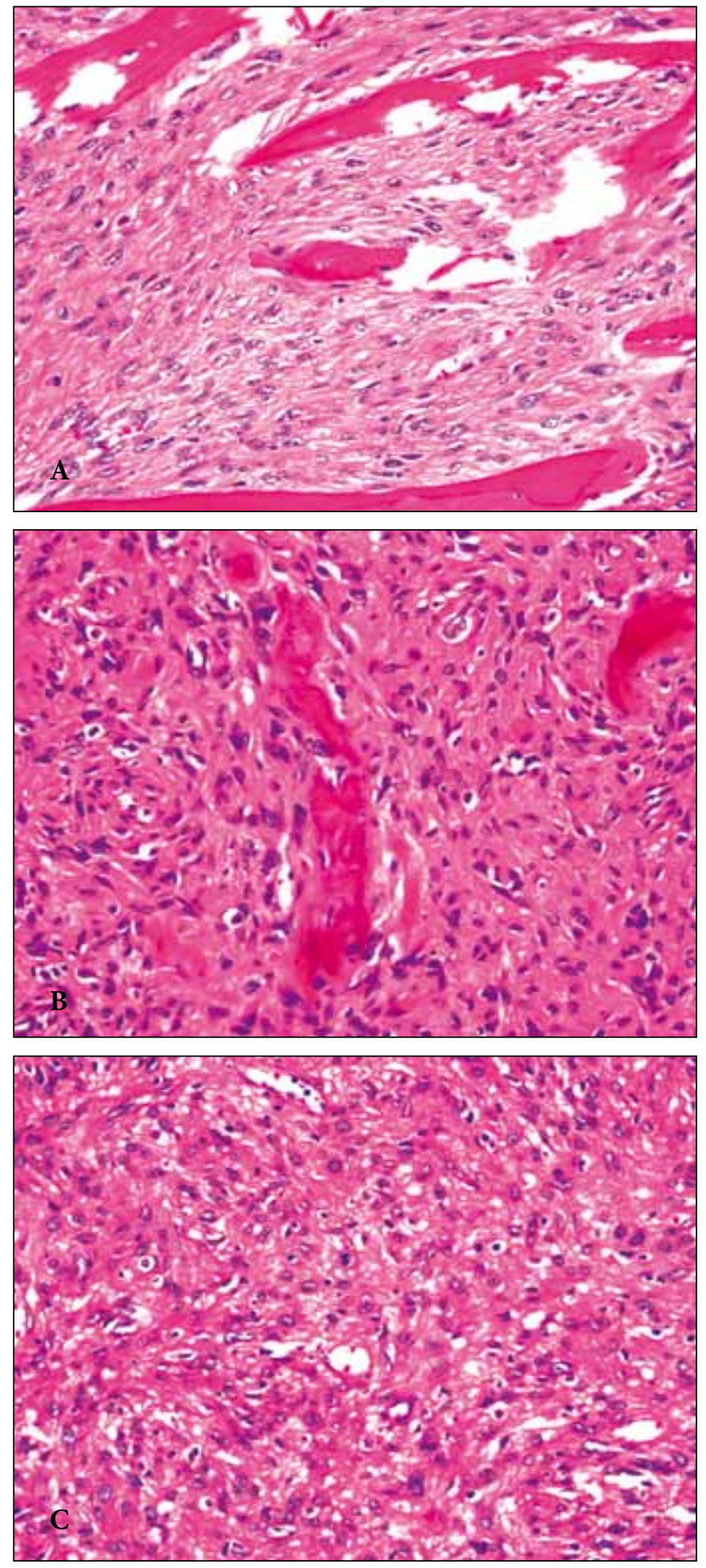

Figure 7: A) Intramedullary low-grade osteosarcoma- Fibroosseous tumor consisting of anastomosing bone trabeculae separated by fibrous tissue (H\&E, x400) B) Spindle cells show moderate nuclear pleomorphism (H\&E, x400) C) Mitotic figures are noted (H\&E, x400). upper end (4). Similarly, 7 of our 15 cases were located in the distal femur.

Radiological investigation shows a large mass with irregular borders and a destructive, mixed lytic and blastic character that generally demonstrates soft tissue invasion in highgrade osteosarcomas while low-grade osteosarcomas are sclerotic and usually arise from the cortical aspect $(14,15)$. Most of our cases had an expansive, sclerotic lesion extending to the surrounding soft tissue. One case had a destructive mass lesion extending to the surrounding soft tissue and the PET-CT showed an appearance consistent with metastasis in the iliac lymph nodes.

The differential diagnosis for intramedullary low-grade sarcoma includes fibrous dysplasia (10-12) while myositis ossificans should be considered for parosteal osteosarcoma (14). The differential diagnosis requires radiological and clinical correlation in addition to microscopical features. The radiologic imaging of myositis ossificans reveals a heterotopic mass with regular borders and peripherally radiodense and centrally radiolucent appearance while microscopic analyses show central spindle myofibroblastic cells and a peripheral area rich in bone with zonal organization (14). Parosteal osteosarcomas have irregular borders, lobulated contours on radiographic imaging and are radiolucent peripherally and radiodense centrally. The radiological appearance of fibrous dysplasia is nonaggressive while microscopy shows woven bone trabeculae with prominent branching in contrast to coarse tumor trabeculae (10-12).

The tumors in our series resembled fibrous dysplasia in some areas. We also had parosteal osteosarcomas that contained osteochondromatous areas, tumors that were similar to myositis ossificans and some with areas resembling giant cell tumors. The components accompanying an intramedullary low-grade osteosarcoma-fibroblastic type may be heterogenous as in our case and this can lead to an misdiagnosis in cases where the biopsy is small and the clinical and radiological data are inadequate.

The diagnostic procedure may be an open biopsy, trucut biopsy, fine needle aspiration or frozen section depending on tumor size, location, the experience and ability of the pathology team. An open biopsy should contain the tumor and surrounding non-tumoral tissue. Tru-cut biopsy materials are helpful in differentiating low-grade and highgrade osteosarcomas on histology especially when they are obtained from areas difficult to access by open biopsy such as vertebrae. Fine needle aspiration biopsies are also quite useful. 
The treatment for high-grade osteosarcomas is surgery in addition to neo-adjuvant and adjuvant treatment while surgery is adequate by itself for low-grade osteosarcomas (1). The 5-year survival rate is $50-80 \%$ for localized conventional high-grade osteosarcomas and $90-100 \%$ for low-grade osteosarcomas (16).

Metastasis is rare in classical parosteal osteosarcoma (1). Parosteal osteosarcomas with high-grade dedifferentiated components, intramedullary extension and a high recurrence rate have a worse prognosis and higher metastasis risk than the clasical type (1,16-20). Deep location, radiolucency and the presence of an ossified area away from the mass should indicate a dedifferentiated component on radiological investigation. Multiple samples are required for these cases. The presence of a dedifferentiated component necessitates wide surgical excision in addition to chemotherapy (1618). There was one local recurrence and one pulmonary metastasis in our series. One case was diagnosed as dedifferentiated parosteal osteosarcoma after multiple samples were obtained.

It is critical to differentiate low-grade osteosarcomas with their better prognosis from the high-grade type, to properly evaluate the overlap between benign lesions in the differential diagnosis and to develop a treatment plan for the patient's diagnosis, treatment and follow-up using an multidisciplinary approach.

\section{REFERENCES}

1. Folpe AL, Inwards CY: Bone and Soft Tissue Pathology. 1st ed. Philadelphia, Elsevier Saunders, 2010, 320-327

2. Rosai J: Rosai and Ackerman's Surgical Pathology. 9th ed. China, Elsevier, 2004, 2153-2157

3. Unni KK, Inwards CY: Dahlin's Bone Tumors, General Aspects and Data on 10,165 Cases. 6th ed. Philadelphia, Lippincott Williams\&Wilkins, 2010, 122-168

4. Kozakewich H, Perez-Atayde AR, Goorin AM, Wilkinson RH, Gebhardt MC, Vawter GF: Osteosarcoma in young children. Cancer 1991, 67:638-642

5. Gadwal SR, Gannon FH, Fanburg-Smith JC, Becoskie EM, Thompson LD: Primary osteosarcoma of the head and neck in pediatric patients: a clinicopathologic study of 22 cases with a review of the literature. Cancer 2001, 91:598-605

6. Ozaki T, Flege S, Liljenqvist U, Hillmann A, Delling G, SalzerKuntschik M, Jürgens $H$, Kotz R, Winkelmann W, Bielack SS: Osteosarcoma of the spine: experience of the Cooperative Osteosarcoma Study Group. Cancer 2002, 94:1069-1077
7. Okada K, Wold LE, Beabout JW, Shives TC: Osteosarcoma of the hand. A clinicopathologic study of 12 cases. Cancer 1993, 72: 719-725

8. Franchi A, Bacchini P, Della Rocca C, Bertoni F: Central lowgrade osteosarcoma with pagetoid bone formation: a potential diagnostic pitfall. Mod Pathol 2004, 17:288-291

9. Inwards CY, Knuutila S: Low Grade Central Osteosarcoma. In Fletcher CDM, Unni KK, Mertens F. (Eds): World Health Organization Classification of Tumours, Pathology \& Genetics, Tumors of Soft Tissue and Bone. Lyon, IARC; 2002, 275-276

10. Inwards CY: Low-Grade Central Osteosarcoma Versus Fibrous Dysplasia Inwards. Pathology Case Reviews 2001, 6:22-27

11. Franceschina MJ, Hankin RC, Irwin RB: Low-grade central osteosarcoma resembling fibrous dysplasia. A report of two cases. Am J Orthop 1997, 26:432-440

12. Muramatsu K, Hashimoto T, Seto S, Gondo T, Ihara K, Taguchi $T$ : Low-grade central osteosarcoma mimicking fibrous dysplasia: a report of two cases. Arch Orthop Trauma Surg 2008, 128:11-15

13. Lin J, Yao L, Mirra JM, Bahk WJ: Osteochondromalike parosteal osteosarcoma: a report of six cases of a new entity. AJR Am J Roentgenol 1998, 170:1571-1577

14. De Silva MV, Reid R: Myositis ossificans and fibroosseous pseudotumor of digits: a clinicopathological review of 64 cases with emphasis on diagnostic pitfalls. Int J Surg Pathol 2003, 11:187-195

15. Hewitt KM, Ellis G, Wiggins R, Bentz BG: Parosteal osteosarcoma: case report and review of the literature. Head Neck 2008, 30:122-126

16. Bertoni F, Bacchini P, Staals EL, Davidovitz P: Dedifferentiated parosteal osteosarcoma: the experience of the Rizzoli Institute. Cancer 2005, 103:2373-2382

17. Iemoto Y, Ushigome S, Fukunaga M, Nikaido T, Asanuma K: Case report 679. Central low-grade osteosarcoma with foci of dedifferentiation. Skeletal Radiol 1991, 20:379-382

18. Takeuchi K, Morii T, Yabe H, Morioka H, Mukai M, Toyama Y: Dedifferentiated parosteal osteosarcoma with well-differentiated metastases. Skeletal Radiol 2006, 35:778-782

19. El Ajmi M, Ksantini R, Chebbi F, Makni A, Rebai W, Daghfous A, Bedioui H, Fteriche F, Jouini M, Kacem M, Ben Safta Z: Abdominal metastasis of a parosteal osteosarcoma of the femur: an unusual cause of large-bowel obstruction. Acta Chir Belg 2009, 109:633-634

20. Cardona DM, Knapik JA, Reith JD: Dedifferentiated parosteal osteosarcoma with giant cell tumor component. Skeletal Radiol, 2008, 37:367-371 